\title{
Persuasion and Manipulation Through Conceptual Metaphors in George Ridpath's Political Writings (1707-1709)
}

\author{
Raquel Sánchez Ruiz, Isabel López Cirugeda \\ University of Castilla-La Mancha, Albacete, Spain
}

\begin{abstract}
The role of the press in politics has always been relevant and noted as it constitutes a way to spread ideologies, to shape and manipulate the readers' opinions, as well as to move and make people join a specific leader or beliefs. Therefore, we could claim that the press is a key persuasive weapon at politicians' disposal. From this standpoint, we have analyzed figurative language in George Ridpath's political writings for The Observator with the aim of examining how this author used conceptual metaphors and metaphtonymies as a weapon to shape and manipulate Great Britain's public opinion during the Stuart period. For this, we have employed the cognitive semantic approach of the Conceptual Metaphor Theory originated by Lakoff and Johnson (1980) and Charteris-Black's pragmatic Critical Metaphor Analysis (2004), since both of them help us interpret and explain the associations that underlie metaphor and how writers conceptualize abstract concepts from bodily experiences to create political myths. Our findings aim at revealing which persuasive metaphorical devices Ridpath used to manipulate public opinion and have permitted us to value his contribution as a very influential, yet controversial, pamphleteer who wrote about the War of the Spanish Succession from Great Britain's viewpoint.
\end{abstract}

Keywords: conceptual metaphor, metaphtonymy, Ridpath, War of the Spanish Succession

\section{Introduction}

\section{Objectives, Data, and Methodology}

The role of the press in politics has always been relevant and noted, as it constitutes a way to reproduce ideologies, to shape and manipulate the readers' opinions, as well as to move and make people join a specific leader or beliefs, so we could claim that the press is a key persuasive weapon at politicians' disposal. This was even more evident "during the late Stuart period (1702-1714), when the spreading of ideas and information relied heavily on pamphlets, periodicals, and newspapers, which both Whigs and Tories and the Ministry itself recognized as organs of political influence" (Crespo-Fernández \& López Campillo, 2011, p. 44).

The aim of this paper is to contribute to the analysis of the role of metaphor and metaphtonymy in discourse by examining how Ridpath used them as a weapon with the intention to shape and manipulate Great Britain's public opinion during the Stuart period. Therefore, we have analyzed metaphors and metaphtonymies in George Ridpath's political writings in the periodical The Observator within a corpus of investigation

Raquel Sánchez Ruiz, lecturer, doctor, Department of Modern Languages, University of Castilla-La Mancha. Isabel López Cirugeda, assistant professor, doctor, Department of Modern Languages, University of Castilla-La Mancha. 
comprising three years (September 1707-January 1709), 147 numbers (53a-100b) and two volumes (VI-VII) devoted to the Spanish campaign and located in the Burney Collection Database in the British Library. ${ }^{1}$ For this, we have followed the cognitive semantic approach of the Conceptual Metaphor Theory and Charteris-Black's (2004) pragmatic Critical Metaphor Analysis.

On the one hand, the Conceptual Metaphor Theory was originated by Lakoff and Johnson (1980) and later modified in Johnson (1987), Lakoff (1987, 1993, 2002), Lakoff and Turner (1989), and Lakoff and Johnson (1999). It is based on the fact that the mind is embodied, while thought is unconscious (Lakoff \& Johnson, 1980). Thus, conceptual metaphors are normally initiated in human bodily experiences of any kind, as thought evolves out of the sensory and motor systems to create metaphorical expressions (Johnson, 1987) and to conceptualize abstract concepts, and in knowledge of the value attached to source domains in particular cultural practices (Charteris-Black, 2011). Under these premises, a metaphor could be understood as a mapping from a source domain (the realm of the physical or more concrete reality) to a target domain (the concept to be reified) (Lakoff, 1993). On the other hand, Critical Metaphor Analysis aims to identify the intentions and ideologies underlying language use through the analysis of metaphors (Charteris-Black, 2005). This approach consists of three stages where metaphors are first identified, then interpreted, and finally explained, which "enables us to identify which metaphors are chosen and to explain why these metaphors are chosen by illustrating how they create political myths" (Charteris-Black, 2011, p. 47). By political myths, we understand a story in which meaning is embodied in recurrent symbols and events as well as an idea which people subscribe to (Charteris-Black, 2005); thus, a predisposition to act (Jowett \& O’Donnell, 1992).

This focus on conceptual metaphors aims to identify possible ideological intentions underlying metaphor choices as conceptual metaphor and metaphtonymy analysis is a way of forming theories about language persuasion (Charteris-Black, 2011) and since this kind of conceptualizations has a highly persuasive force and they stand as a means of creating, organizing and understanding reality (Crespo-Fernández, 2006). Furthermore, understanding the systematic nature of metaphor choices reveals how belief systems are conceived within persuasive language of political leadership (Charteris-Black, 2005), and the metaphors used every day reflect our way of understanding the world (Hellín García, 2009); and although Lakoff and Johnson's theory mainly refers to daily life, this approach can be applied to the study of metaphor within politics.

To assist in the interpretation of conceptual metaphors, we have employed the empirical method of Critical Metaphor Analysis, which consists of identifying candidate metaphors-metaphorical expressions-and metaphor keywords ${ }^{2}$ — words used metaphorically — and classifying them according to their linguistic content or "source domain" and what they describe or "target domain". Then, Cognitive Semantics is applied to infer the assumptions that underlie metaphor use and to explain the relationship between its linguistic choices and metaphorical meanings. When classifying and counting metaphors, we have followed Charteris-Black's method (2011), that is, metaphors from the same source domain occurring in the same phrase were counted as single metaphors. Where there was evidence of different source domains in the same phrase, we identified which source

\footnotetext{
1 This paper is included in the research project George Ridpath y la Guerra de Sucesión Española, HU20101576 (George Ridpath and the War of the Spanish Succession) financed by the University of Castilla-La Mancha. Data could be accessed thanks to a research stay in Roehampton University and the British Library (London), which was also financed by the University of Castilla-La Mancha.

2 These two terms in italics are retrieved from Hellín García's approach in metaphor identification (2009, p. 132).
} 
domain was primary and only counted this, especially where the secondary use was also part of another metaphor or metaphtonymy. In this last case, metaphor priority was given according to the socio-cultural context of the author and his texts. For example, in "(...) cost us a great Deal of more Blood” (Ridpath, 1709, p. 71), we find "people are money" and "blood is money"; thus, we prioritize the first one since the second is a metaphtonymy.

Discourse analysis has always been a subject of interest from Aristotle's Politics and Rhetoric to the present day. In the last thirty years, with the development of different discourse analysis methods and approaches such as Critical Discourse Analysis (CDA), as in Fairclough (1995), van Dijk (2001), Wodak and Chilton (2005) and concretely Political Discourse Analysis (PDA), as in Wilson (2001) and Chilton (2004), studies tend to focus on presidential speeches or performances, such as those by Fernández Lagunilla (1999), Horváth (2007), Aponte-Moreno (2008), Hellín García (2009), Wang (2010), Charteris-Black (2011), or López Cirugeda and Sánchez Ruiz $(2013,2014)$. The choice of a corpus of writings by Ridpath is not random because, while there is a growing literature addressing figurative language within political discourse, there is a dearth of information regarding political persuasion in Great Britain during the late Stuart period (Barker, 2000; Black, 2001). There is even less research concerning the War of the Spanish Succession despite being considered as one of the first historic events when a widespread national debate was generated and different authors' pens were at the service of the Whig or Tory cause, who used all types of political propaganda (Müllenbrock, 1997; López Campillo, 2009). Concerning the authors, most of the studies focus on writers like Jonathan Swift (Downie, 1984; Oakleaf, 2008) and Daniel Defoe (Schonhorn, 1991; McKim, 2008; López Campillo, 2010), but they have overlooked the important role of George Ridpath. As McLeod and McLeod (1979) noted, "while Ridpath is mentioned in almost every recent work on the reign of Anne, he has never received the attention which he deserves" (p. 194). In fact, George Ridpath's language as a political and polemical journalist has only recently become an object of study (Crespo-Fernández \& López Campillo, 2011; Sánchez Ruiz, 2014). Therefore, this study aims to bridge a gap in rhetorical studies about the political discourse of an author who, though unfamiliar to the public, played a relevant role in influencing Great Britain's public opinion in a period when the press became a powerful tool to spread ideologies, to persuade and to legitimate sources and institutions within the political and social spheres.

\section{Ridpath and The Observator}

George Ridpath (1660? - 1726) was a prominent and polemical Scottish journalist and pamphleteer of the Whig faction during the Stuart period, when the press was recognized as an organ of political influence and, thus, pamphlets, periodicals, and newspapers started to be used to spread ideas and shape public opinion. ${ }^{3} \mathrm{He}$ was born and educated in Berwickshire until he went to Edinburgh University. As he held strong anti-Catholic and Presbyterian views - he was even affirmed to be "the head of the Presbyterian party in Scotland" (Monro, d1715?) - he actively participated in the burning of the Pope in effigy together with some other students and was charged with threatening to burn the provost's house, for what he was imprisoned for five weeks. After that, he moved to London to write for a living (Ridpath, 1694, pp. 52-56). Then, he was accused of being the author of three libels in The Observator and was found guilty of two of them. So as to escape the authorities, he disappeared and went to Scotland, and thence to Holland. He came back to England when George I accessed to

\footnotetext{
${ }^{3}$ For further information on the persuasive role of pamphlets, periodicals, and newspapers in politics during the late Stuart period in England (see López Campillo, 2009, pp. 189-195).
} 
the throne and was made a patentee for serving the commissioners of the customs in Scotland (W. R. McLeod \& V. B. McLeod, 1979).

Ridpath's role within Great Britain's public opinion was decisive as some loyal voters were believed to shift sides due to the persuasive power of the press. However, this kind of voters preferred the Tories and only sided with the Whigs when the succession seemed to be in danger (Speck, 1970). The vacancy of the Spanish throne posed a vital opportunity to destroy the powerful entente of this nation with France through the proposal of an heir from a different kingdom. This would pave the way for Britain to succeed in her historical ambition to become the main world power both in Europe and America. Therefore, it was necessary for Ridpath to persuade his compatriots about the illegitimacy of the French candidate, Philip of Anjou, and the characterization of his nation as naturally evil. Moreover, Ridpath "contributed to the great political debates of the reign of Queen Anne from 1688 to 1714" (Crespo-Fernández \& López Campillo, 2011, p. 47) and was "one of the best pens in England" according to Jonathan Swift (1824, p. 297).

He was also the successor of John Tutchin - when he died in 1707-in editing The Observator, one of the leading journals in the Stuart period, claimed to be the best country periodical (Dunton, 1818), and the most important political organ of the Whigs against the government (Müllenbrock, 1997). The Observator was a twice-weekly political journal, primarily devoted to denouncing fraud and abuse within the government and was founded in London in 1702 (cf. Auchter, 2001, pp. 253-255). One of its main characteristics-and one directly connected to manipulation - is its particular, Platonic-style dialogued structure by two interlocutors: Roger, a countryman, particularly talented at voicing his own people's opinion, and an educated gentleman who called himself The Observer thanks to his detailed examination of national and international affairs. All the words by Roger conveniently prepared the ground for the speech of his master, with the contents Ridpath wanted to transmit to his audience.

\section{Metaphors and Metaphtonymies in Political Discourse Analysis: Definitions and Classifications}

Lakoff and Johnson (1980) state that a metaphor "is pervasive in everyday life, not just in language but in thought and action" as "our ordinary conceptual system, in terms of which we both think and act, is fundamentally metaphorical in nature" (p. 3). For Charteris-Black (2004) a metaphor is

a linguistic representation that results from the shift in the use of a word or phrase from the context or domain in which it is expected to occur to another context or domain where it is not expected to occur, thereby causing semantic tension. (p. 21)

By the term metaphor we understand a device which structures our conceptual system and, at the same time, provides a particular way of understanding reality and representing our experience; that is, a mapping or a set of correspondences from a source domain, or the realm of the physical or more concrete reality, to a target domain or the concept to be reified (Lakoff, 1993). Thus, a conceptual metaphor ontologically matches two semantic fields or domains (Hellín García, 2009). For instance, in our corpus, the semantic field of war (target domain) is explained through terms normally related to body, buildings, or race (source domains). It must be also considered that "[m]etaphorical conceptualization in natural situations occur under two simultaneous pressures: the pressure of embodiment and the pressure of context", determined by local culture (Kövecses, 2002, p. 204). Moreover, the 
priority given to certain values when structuring metaphors (Lakoff \& Johnson, 1980) implies a meaningful perception of that specific concept (Crespo-Fernández, 2008). Therefore,

[the] metaphor is a very effective means through which potential leaders can communicate with the "voice within" because it creates evocative representations of the speaker and their policies by arousing emotions and forms part of the process by which an audience reconstructs the causal relationships of an argument. (Charteris-Black, 2005, pp. 10-11)

Herrero Ruiz (2009) describes metonymy as a device which only involves one conceptual domain; that is, the mapping occurs within a single domain and not across domains as in metaphors. For example, "the soul stands for a person". They are mainly used for reference, as we can refer to an entity in a schema by referring to another entity in the same schema. It must also be noted that many times, metonymies merge with metaphors creating metonymic metaphors - for which Goossens (1990) coined the word metaphtonymy - grounded in bodily and social experiences to recur structures coming from personal perceptions and bodily functioning (Johnson, 1987; Lakoff, 1999).

Within the Conceptual Metaphor Theory, different scholars have proposed various typologies of metaphorical conceptualizations according to different criteria. ${ }^{4}$ Considering that many conceptualizations are not based on our daily experience, Grady (1997) distinguished between "complex metaphors" (for instance, "theories are buildings") and "primary metaphors" ("logical organization is physical structure"). Complex metaphors are composed of primary metaphors, which, at the same time, are correlations of a subjective experience with a physical experience.

According to the correspondences observed in the metaphorical process, Grady (1999) defined "correlation metaphors", on the one hand, and "resemblance metaphors", on the other hand. Correlation metaphors - usually referred to as primary metaphors - are based on two experiential domains which, though independent in a principle, easily co-occur in our minds. For example, "states are locations". On the contrary, resemblance metaphors are not related to sensory-motor experiences, but are based on the non-literal perception of some characteristics shared by the source domain and the target domain, as happens in "people are machines" (Lakoff \& Johnson, 1980, p. 132). This non-literal use of language can be grounded in the perceived similarity between objects, situations or events (Iza Erviti, 2012).

Lakoff and Johnson (1980) also distinguished between "ontological metaphors", which derived from our experience in relation to physical objects; thus, they are primary metaphors as well, and "orientational metaphors", that is, those which organize a "whole system of concepts with respect to one another" (Lakoff \& Johnson, 1980, p. 15). "Animal metaphors" play an important role within Ridpath's political writings as the analysis will demonstrate. This type of metaphor is framed within the Great Chain of Being (Lakoff \& Turner, 1989), which organizes entities in the following hierarchy: humans, animals, plants, objects, and artifacts, and defines their shared physical and behavioral attributes. Kövecses (2002, p. 201) defines animal metaphors as those that permit to understand two human features in terms of others that are culturally attributed to animals and vice versa (through both metaphors "people are animals" or depersonification and "animals are people" or personification).

Finally, as suggested before, our mental structures are highly conditioned by the physical nature of our

\footnotetext{
${ }^{4}$ For a detailed explanation of the criteria used in the classification and the result of metaphors (see Caballero, 2006, pp. 74-79).
} 
perception, which is defined as embodiment by Cognitive Linguistics (Johnson, 1987) and may be applied to every metaphor. The fact that language does not always reflect the biological connection between stimuli and the senses refers to mind mapping and is labeled under the term "synesthesia" or "cross-sensory metaphors". The

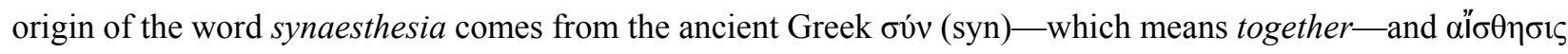
(aisthēsis)-which means sensation; thus, this figure of speech consists in voluntarily mixing sensory or cognitive pathways, especially those related to colors and flavors.

\section{Analysis of Metaphors and Metaphtonymies and Results}

After providing the theoretical framework of the discourse analysis approaches, including persuasion and the figurative devices in which this study is embedded, we proceed to explain the results of our research on metaphors and metaphtonymies. Due to the space limitations and the extension of the corpus of this study, just some representative examples will be provided for each of them.

First of all, according to their source domains, metaphors and metaphtonymies have been classified into eight categories, which are: animals, body—including health and sickness, food, light, life and death, money, power, and weather. Synaesthesia or cross-sensory metaphors will be also commented as well as the fruitful metaphors in the corpus whose target domains are nation or war.

The first category is animals, which yields dysphemistic ${ }^{5}$ conceptual metaphors. The comparison between men and animals is an efficient resource to insult and offend. As Kövecses (2002) notes, the conceptual metaphor "violent human behaviour is animal behaviour" generates unequivocal insulting terms from animal lexicon. This type of metaphorical depersonifications shows the close relationship between this device and dysphemism and demonstrates that metaphors may constitute an offensive discourse strategy. In our corpus, this resource is consistently applied to the French, the Catholics and those who support them in any possible way as a means to depreciate these collectives and dismantle Philip of Anjou's aspirations to the throne of Spain. Thus, the following two examples constitute the conceptual metaphor "people are animals", which is an ontological or a resemblance metaphor:

(1) let them bark on, Roger $\left(1708\right.$, p. 1). ${ }^{6}$

(2) old Rats love to smell Cheese (1707, p. 58).

Comparing, in this case, the enemy - that is, the French and Catholics - to animals has two main effects. On the one hand, according to van Dijk's polarization (1999) it negatively represents the outgroup (the French and Catholics) and, on the contrary, it positively self-represents Ridpath's beliefs, interests and opinions (the British and Protestants'). On the other hand, it justifies their extinction; in fact, this even becomes a duty for the benefit of society (Crespo-Fernández, 2013).

\footnotetext{
5 Allan and Burridge (1991, pp. 1, 26) define dysphemism as "speaking offensively" or the process by which the most pejorative traits of the taboo are highlighted with an offensive aim to the addressee or to the denotatum or the concept itself. Dysphemism interacts with figurative language because, as Crespo-Fernández (2011, p. 54) states, speakers turn to it—especially metaphorization - to cope with taboo topics. Thus, this author affirms that metaphor "plays a crucial role in the way we manage forbidden concepts and manipulate the taboo referent, insofar as it is at the user's disposal to model the distasteful concept and present it without its pejorative overtones or, by contrast, with an intensification of its most unacceptable conceptual traits" (Crespo-Fernández, 2011, p. 54).

${ }^{6}$ As the whole of our corpus was written by Ridpath, references appear without any surname. Furthermore, the original spelling has been respected at all times.
} 
The second category is body. Both metaphors are considered to be related to the human body since- as Johnson (1987) states - metaphorical expressions originate in underlying metaphors that derive from human bodily and neural experiences of space, movement and containment, among others (Charteris-Black, 2011), hence the great number of examples found in our corpus. Besides, Musolff (2010) affirms that body metaphors are typically used within politics—body politic, which implies the following notions: The body must be complex, as it can be taken apart (e.g., dismembered); there is a hierarchy of members depending on their position and the importance of their vital function; and also a differentiation of states of health and sickness, where the latter normally invokes a follow-up scenario of diagnosis and therapy and/or death.

Attempting the task of explaining international affairs to the citizens of Great Britain implies the repeated use of concepts of geography, politics, and religion, and Ridpath related them all to the source domain body. Furthermore, Ridpath seems to be aware of his personal preference: e.g., "the Body Politick" (1707, p. 66). Taking into account the above, the conceptual metaphors resulted from the analysis can be divided into several subcategories. One of them attributes to the body those properties of the mind or the soul through the metaphtonymy "the soul stands for a person" and "the soul is a valuable commodity", as it is seen in the following example:

(3) Parliaments ought to convene for the Salvation of the Souls of the Trespassers (1708, p. 28).

Ridpath manages to make mind and soul appear more tangible and closer to the less-learned readers. Thence, his political campaigns are directly linked to one of the main aspirations of the population of his time; that is, saving their souls.

A second subcategory deals with sickness and venom. These metaphors imply the personification of Britain and her society, so that everything which is not convenient - namely, Catholicism as identified with French influence — is considered damaging in the same terms used for living creatures: "principles are a plague" $(4,5)$ or "popish principles are poison" $(6,7)$;

(4) The Rehearser spreads Popish Principles (1708, p. 50).

(5) such Principles are suffer'd to be spread in our Universities (1708, p. 53).

(6) by poisoning the Subjects with false Principles against our Constitution (1708, p. 94).

(7) poisonous and idolatrous Doctrines of the Church of Rome (1709, p. 66).

Example (4) shows a conception of Popish principles as intrinsically opposed to the real values of the British, those of the Constitution, sacralized by Ridpath in example (6). At the same time, (4) and (5) can be considered as secondary metaphors derived from the conception of England as a living creature suffering from the spread of poisonous principles - namely, those of the Pope — due to the action of certain media and universities.

With many metaphors, the author tries to persuade the reader to believe that Catholics are the intrinsic enemy both inside and outside Britain, for which he also employs dysphemistic language. Religious coexistence had derived into a highly touchy issue and eventually caused the end of the Stuart period when George of Hanover was elected as the new monarch amongst other Queen Anne's relatives due to his Protestant faith. Therefore, manipulation is observed when Ridpath insistently tries to connect the Protestant faith professed by

\footnotetext{
7 This (plague) is a dysphemistic expression and also a direct reference to animal metaphors, which — as said before- justifies the extinction of Catholic principles; in fact, its extinction becomes a duty to preserve society and even humanity (Crespo-Fernández, 2013, p. 318).
} 
most Britons to the political campaigns, he is supporting in a specific moment, first in favor of the Whigs and then of the Tories. Some other morals are conveyed under the metaphor "drinking and gaming are a plague of the nation", for instance:

(8) for gaming and drinking with the Gaugers, and keeping them from their Business, are a Plague to the Nation (1708, p. 22).

By stating that "crimes are illnesses", the author intends to affirm that they can be somehow cured, for example:

(9) whom the Pillory itself has not been able to cure of his Itch of Slander (1708, p. 90).

The third subcategory is that of body metaphtonymies. The conceptual metaphors identifying institutions or abstract concepts with parts of the body permits to identify what is more or less important (Musolff, 2010, p. 25):

(10) Ireland must be a lame Leg for 'em to mump with (1707, p. 55).

(11) upon the Foot of our Ancient Constitution (1707, p. 59).

(12) the Head of the Administration (1709, p. 86).

(13) the Parliament is approaching (1707, p. 62).

(14) headed by the Court of Rome (1709, p. 86).

Example (10), representative of the primary or correlation metaphor "parts of the body are locations", visually shows that this territory is considered as a heavy burden for Britain. In (11), it is noted that this document constitutes the base on which a society is founded. Normally, the upper parts of the body represent the most important people within a group, such as in (12), it is also implied that the Administration is composed of thinkers, as the head is bond to the brain. Moreover, for Ridpath, politics and its representative entities are alive, so they move likewise, as in example (13), in which the Parliament is approaching. These concepts are embodied through the metaphors "politics is a body", since the Parliament can move because it has legs, which at the same time is a personification. The same happens in example (14), where the Catholic Church is implied to be the head of the body.

The third category is food, which includes the following positive conceptual metaphors associated with this source domain: "liberties are food", "principles are food", and "things are food". With them, Ridpath clearly establishes which things are as essential as eating for human beings: liberty, British and Protestant principles, and some kind of government. In fact, these three things can be also considered nourishment for people.

However, there is also a negative association: "damnation is food". Consider the following examples:

(15) by obliging unworthy Receivers to eat and drink their own Damnation (1708, p. 29).

(16) to give him a little Taste of his Popish Sacrifice (1709, p. 58).

In example (15), the sacrament of communion, metaphorically represented by the body functions of eating and drinking, is described as sacrilegious since its results are described as condemnatory. Even more, communion itself becomes an equivalent of doom in expressions like the one in example (16).

Light is the fourth source domain for conceptual metaphors and metaphtonymies in our corpus. This is a well-known resource because, as Lakoff and Turner (1989) state, light sends a positive message since it symbolizes knowledge, life and human survival:

(17) wherein Satan acted more at first under Disguise of an Angel of Light (1708, p. 19).

In our research, it only serves to create a single but important figure of this kind: "religion is light", such as 
in the previous example. Again, through this kind of metaphors, Ridpath wants to appeal to morals within the readers and have an influence on them regarding his own Presbyterian and anti-Catholic religious ideas. The contrast within this religious pairing — Satan vs. God or the Angel of Light—is a personification of good and evil forces which emphasizes its metaphorical meaning through a cliché; that is, the Devil-in all of his names - confronted with God is a source of dysphemism. Example (17) identifies again Catholics with evil through a Bible quote, 2 Cor. 11:14, stating that the enemy takes the appearance of goodness so as to confuse souls.

The fifth category, life and death, is closely related to the second, body, although it is considered aside, owing to the fact that the former does not directly involve the latter in every case as the examples mentioned above. Take the following examples:

(18) to pluck up the Roots of an arbitrary Power (1708, p. 97).

(19) against the Growth of Popery (1709, p. 90).

(20) pull up the Roots of Jacobitism (1708, p. 10).

(21) when Men of no Religion see it prostituted contrary to our Saviour's Institution (1708, p. 29).

This form of personification somehow suggests which things, even abstract or psychological, are important or valuable for humans, such as power, usually linked to natural phenomena, as in (18) and (19). Example (19) is related to the religion hated by Ridpath, who observes an increase of devotees in favor of the opposite faction's pretender and beliefs and who intends to raise the number of Protestants to the detriment of the Catholics (20). By using the metaphorical expression "prostituted" in (21), Ridpath directly offends Catholics by calling them atheists - used as a dysphemistic adjective because it represents a face affront or a loss of face, since the most pejorative traits of the taboo (prostitution) are highlighted with the intention to directly insult the addressee - and accuses them of seriously perverting the notion of Church.

The sixth category, money, is one of the most repeatedly noted in the corpus, especially those conveying that "countries are money and a treasure". This way of conceptualizing thought reveals Ridpath's profound patriotic beliefs and feelings - as an author who always defended his country and Her Majesty — as well as which issues are important in times of war, such as: possessing concrete countries or places for achieving success:

(22) we have lost good Part of our Subject, in not taking Thoulon (1707, p. 53).

(23) will not endanger the Loss of Spain, for the Sake of Recovering Naples (1707, p. 67).

The conceptual metaphor "liberty is a valuable commodity" highlights the relevance of freedom, especially when its loss has been noticed:

(24) we seem to have lost that Spirit of Liberty (1708, p. 38).

(25) Liberty for preserving the Freedom of Mankind (1709, p. 92).

Also the universal concern of time as money due to the fact that personal time is limited:

(26) I may spend my time much better (1707, p. 53).

Finally, someone's most valuable possession, life, is also mentioned here. It is commented aside because it is not considered relevant only in times of war like the ones we just mentioned. "Life is a valuable commodity" is both a conceptual metaphor which highlights its importance and a euphemistic expression to avoid the taboo of death. The following examples illustrate this:

(27) had very near lost his Life (1708, p. 53). 
(28) the Loss of abundance of Lives (1709, p. 99).

(29) Money and Blood they have spent during the War (1707, p. 79).

The metaphtonymy "the soul is a valuable commodity", which identifies souls with human beings, especially for specific societies, could be considered as a reformulation of the previous idea:

(30) the Loss of Souls of equal Importance (1708, p. 51).

The seventh category is power, represented by the following example:

(31) we have no Security against Popishes getting into Places of Power and Trust (1708, p. 29).

This example reflects that sometimes power is represented somewhere, which, at the same time, illustrates that "power is a place" through a primary or correlation metaphor. Moreover, it shows that what dominates people, especially in times of war, is people's position within society and - a closely related factor-money, degree of necessity, the press and words, religious or political beliefs, and violence, as expressed in the above-mentioned metaphor as well as "money is power", "management is power", and "necessity is power". The fact that words and the press can dominate people confirms that words are a powerful weapon to manipulate and shape the public opinion of certain sectors of society or, even, whole countries.

The eighth category of metaphors is weather, a frequent topic in Great Britain's small talk. It is typical for people to compare events or situations to common personal ones. Then, bad weather-which conceptualizes "difficult situations are cold and rain"- - represents rough times or unfortunate events, such as in:

(32) the Deponent should go Home in that naked Condition in the Cold and Rain (1708, p. 29).

(33) things look still cloudy (1709, p. 75).

(34) you must not look on the black clouds only (1707, p. 68).

The naval world is also closely linked to historical tradition in Great Britain, since it is an island, which is why the author compares some of the unlucky consequences of the war to the sinking of a ship; thus, using a resemblance metaphor which represents "difficult situations are a sinking boat":

(35) sinking Trade (1707, p. 69).

(36) to lay our Country under Water (1709, p. 72).

Besides, other synaesthetic conceptual metaphors represent typical prejudice or assumptions. For example, negative situations or even people do not smell good ("enemies stink or things stink or have an aroma")- this also constitutes a lexicalized metaphor, as Ibarretxe-Antuñano (1999) notes, which adds dysphemistic connotations to the verb. Some experiences are so real that they have a tangible or a real physical impact ("oaken towels are a flavor"). And, depending on their good or bad sense, words may have a lighter or darker color respectively ("words are colors"). Again this last one is linked to light metaphors and religion in the sense that good is represented by white, and so light colors, and evil by black, and so dark colors (Lakoff \& Turner, 1989; Gibbs, 2011).

Particularly abundant are the conceptual metaphors, whose target domains are nation or war. The former includes everything related uniquely to it, unlike previous examples, and is reduced to two conceptual metaphors: "the enemy's nation is a monster" and "the nation is a building". On the one hand, the former, then, constitutes an example of positive representation (van Dijk, 2008), since the nation (we) are the good ones and the enemy (they) are the bad ones. Moreover, it is also an animal metaphor and depersonification, because it conceptualizes "the enemy is a beast" and, thus, compares them to a social danger which must be exterminated. On the other hand, the 
latter is a characteristic image of a country illustrated by a primary, ontological, or correlation metaphor:

(37) defend the Walls of our Nation (1707, p. 62).

(38) defending the Walls of Great Britain (1707, p. 82).

(39) the Crown was settl'd on her Majesty (1709, p. 61).

(40) the Breaches he made upon your Constitution (1708, p. 88).

Example (37), frequently repeated throughout the text, shows Britain as a home for every patriot and, therefore, something which must be preserved from outsiders $(37,38)$; which has foundations (39) or which might have the same problems as a building (40).

On the other hand, there is the target domain of war. The conceptual metaphors in this classification can, at the same time, be divided into two subcategories: pure war and tangible consequences of war. Consider these examples from the first subcategory:

(41) furnish their Contingents (1707, p. 73).

(42) in their first Campaign, we have demolish'd the Lines which he had erected at so much Expence (1708, p. 49).

While example (41) implies that wars can be prepared from the beginning, step by step, the way a building is (42), once a war is ongoing, people must choose a place to be: with or without a specific faction. Both of them express the idea that "campaigns are buildings".

(43) making the Assault on the weakest Side (1707, p. 58).

(44) who are willing to stand by your Majesty in this War (1707, p. 88).

The previous examples conceptualize the idea that "war has sides". Moreover, the competition between both sides suggests that a "war is a race", which is explicitly stated in:

(45) especially had he been join'd by the Scotch Racers (1708, p. 13).

(46) when the Fight becomes a Chase. He wins the Fight, that wins the Race (1708, p. 14).

As mentioned above, people's importance within a group is associated with the parts of the body and so it happens with war. Thus, the most relevant aspects are centrally located. Moreover, they take for granted that "war is parts of the body", as the following examples show:

(47) as settl'd on the Foot of the Revolution (1707, p. 88).

(48) had they a Body of his Troops (1709, p. 92).

The second subcategory, tangible consequences of war, directly connects this kind of metaphors to synaesthesia. A line can be drawn to separate beneficial and unfavorable results: within the former, success, truth, and trust are included; within the latter, disgrace. The rest have been divided into politics, will, and words and can be considered neutral or, rather, ambiguous, since the way they are employed defines whether they are positive or negative. It must be borne in mind that these concepts - politics, time, and words - are not inherently bond to the consequences of war. However, their relationship here is pragmatic since the context links them to that domain of war.

Then, concerning politics, the enemy's actions are always reported to be seen, touched, or heard, and so are synaesthetic as well:

(49) the Emperor's Affairs would have been much mended (1707, p. 53).

(50) what a Noise have you made about the Scots (1707, p. 56). 
These examples show that "disgrace is visible" or "tangible", "politics is tangible", and "success can be heard". Thoughts are visible and even tangible to the extent that people can exchange and see them, even arrive to them:

(51) give me your Opinion (1707, p. 72).

(52) the very Mark and Butt of all their Malice (1709, p. 78).

(53) brought them to Reason (1709, p. 76).

Apart from their usual function, words can also be visible or tangible, as in the following expression, which is intended to connect the two nations by recurring to the symbol of a bridge:

(54) keep open the Communication with Catalonia (1707, p. 84).

\section{Conclusion}

The considerations mentioned above lead us to claim that Ridpath used metaphors and metaphtonymies during the War of the Spanish Succession with a very clear intention: to persuade his compatriots about the illegitimacy of the French and Catholic candidate to the Spanish throne-Philip of Anjou—by representing France and its allies as intrinsically evil; and about the convenience of a Protestant candidate of the House of Hanover. This implies that a foreign episode was considered vital for domestic affairs as the decline of the Spanish Empire could become a turning point for the expansion of the newly-unified Britain.

Regarding the interaction between each device and persuasion, metaphors have enabled us to analyze the thoughts of the author since they are based on the readers' common situations and personal experiences. And the way he creates and organizes abstract concepts represents his readers' world so as to influence their rational, moral, and emotional response. In the particular case of synaesthesia, the figure of speech has clarified how Ridpath related his senses to create new metaphors, especially to represent typical prejudice or assumptions. Moreover, it has also been shown - with several examples - that figurative language, especially metaphors, constitutes a fruitful source of dysphemism due to its power to mask and create face affronts or offence.

On the one hand, the analysis reveals the five key and most repeated concepts: body, food, life, war, and words. On the other hand, through our analysis of devices and examples, four conclusions can be drawn. First, Ridpath's political writings recurred to morals - an aspect which is remarked by the dialogued structure of his periodical - with the intention to have an influence on readers according to his own Presbyterian and anti-Catholic religious ideas, portrayed as the essence of the national entity. Second, his use of language appealed to English patriotic beliefs and feelings, as well as the way in which he positioned himself towards war in its different stages throughout history, first for it and, then, against. With that purpose, he pictures Britain as a house which must be protected from intruders. Both nations and the Church are personified as individuals fighting. Moreover, territories are considered as valuable commodities that must be possessed by Britain or otherwise will fall into French hands. Third, by comparing abstract things or the abstract representation of human beings, such as their minds and their souls to tangible ones, the author intended to appeal to the saving of their souls, knowing it was a matter of vital interest for the people of the time. Finally, the author gave relevance to words and metaphorical devices related to them so as to manipulate and shape the public opinion of certain groups or, even, whole countries.

After these results, two things could be claimed. Firstly, the analysis constitutes another example by which 
the model of Cognitive Linguistics provides solid tools for understanding and evaluating how important political writings and the press were in Great Britain during the War of the Spanish Succession by researching on one of the most relevant authors of that time, that is, George Ridpath. Secondly, that the press is a key persuasive weapon, especially at politicians' disposal.

\section{References}

Aponte-Moreno, M. (2008). Metaphors in Hugo Chávez's political discourse: Conceptualizing nation, revolution and opposition. Saarbrücken: VDM Verlag Dr. Müller.

Aristotle. (350 B.C.E). Politics. (B. Jowett, Trans.). Retrieved from http://classics.mit.edu/Aristotle/politics.html

Aristotle. (n.d.). Rhetoric. (W. R. Roberts, Trans.). Retrieved September 27, 2011 from http://rhetoric.eserver.org/aristotle/

Auchter, D. (2001). Dictionary of literary and dramatic censorship in Tudor and Stuart England. Westport: Library of Congress.

Barker, H. (2000). Newspapers, politics and English society, 1695-1855. Harlow: Longman.

Black, J. (2001). The English press 1621-1861. Gloucestershire: Sutton Publishing.

Caballero, R. (2006). Reviewing space: Figurative language in architects' assessment of built space. Berlin: Mouton de Gruyter.

Charteris-Black, J. (2004). Corpus approaches to critical metaphor analysis. New York: Palgrave Macmillan.

Charteris-Black, J. (2005). Persuasion, legitimacy and leadership. In J. Charteris-Black (Ed.), Politicians and rhetoric: The persuasive power of metaphor (pp. 1-31). Hampshire/New York: Palgrave Macmillan.

Charteris-Black, J. (2011). Politicians and rhetoric: The persuasive power of metaphor. New York: Palgrave MacMillan.

Chilton, P. (2004). Analysing political discourse: Theory and practice. London/New York: Routledge.

Crespo-Fernández, E. (2006). The language of death: Euphemism and conceptual metaphorization in Victorian obituaries. SKY Journal of Linguistics, 19, 101-130.

Crespo-Fernández, E. (2008). Sex-related euphemism and dysphemism: An analysis in terms of conceptual metaphor theory. Atlantis Journal of the Spanish Association of Anglo-American Studies, 30(2), 95-110.

Crespo-Fernández, E. (2011). Conceptual metaphors in taboo-induced lexical variation. Revista Alicantina de Estudios Ingleses, 24, 53-71.

Crespo-Fernández, E. (2013). Words as weapons for mass persuasion: Dysphemism in Churchill's Wartime Speeches. Text \& Talk, 33(3), 311-330.

Crespo-Fernández, E., \& López Campillo, R. M. (2011). Persuasive rhetoric in George Ridpath's political writings. ES Revista de Filología Inglesa, 32, 43-67.

Downie, J. A. (1984). Jonathan Swift, political writer. London: Routledge.

Dunton, J. (1818). The life and errors of John Dunton, citizen of London with the lives and characteristics of more than a thousand contemporary divines, and other persons of literary eminence (Vol. II). London: J. Nichols, son \& Bentley.

Fairclough, N. (1995). Critical discourse analysis: Papers in the critical study of language. London: Longman.

Fernández Lagunilla, M. (1999). La lengua en la comunicación politica. La palabra del poder (Language in political communication. The words of power). Madrid: Arco Libros.

Gibbs, R. W. (2011). Evaluating conceptual metaphor theory. Discourse Processes, 48, 529-562.

Goossens, L. (1990). Metaphtonymy: The interaction of metaphor and metonymy in expressions for linguistic action. Cognitive Linguistics, 3, 323-340.

Grady, J. (1997). Theories are buildings revisited. Cognitive Linguistics, 4(8), 267-290.

Grady, J. (1999). A typology of motivation for conceptual metaphor: Correlation vs. resemblance. In R. W. Gibbs \& G. J. Steen (Eds.), Metaphor in cognitive linguistics (pp. 79-100). Amsterdam/Philadelphia: John Benjamins.

Hellín García, M. J. (2009). Fight metaphors in Spain's presidential speeches: J. L. Rodríguez Zapatero (2004-2007). Revista Alicantina de Estudios Ingleses, 22, 127-153.

Herrero Ruiz, J. (2009). Understanding tropes: At the crossroads between pragmatics and cognition. Frankfurt am Main: Peter Lang.

Horváth, J. (2007). Pre 9/11 inaugural address of president George W. Bush: Critical discourse analysis. Topics in Linguistics, 1, $58-61$.

Ibarretxe-Antuñano, I. (1999). Metaphorical mappings in the sense of smell. In R. W. Gibbs \& G. J. Steen (Eds.), Metaphor in cognitive linguistics (pp. 29-45). Amsterdam/Philadelphia: John Benjamins. 
Iza Erviti, A. (2012). Resemblance operations and conceptual complexity in animal metaphors. Revista de Lingüistica y Lenguas Aplicadas, 7, 163-178.

Johnson, M. (1987). The body in the mind. Chicago: The University of Chicago Press.

Jowett, G. S., \& O’Donnell, V. (1992). Propaganda and persuasion. London/Newbury Park: Sage.

Kövecses, Z. (2002). Metaphor: A practical introduction. Oxford/New York: Oxford University Press.

Kövecses, Z. (2010). Metaphor and culture. Acta Universitatis Sapientiae, Philologica, 2(2), 197-220.

Lakoff, G. (1987). Women, fire and dangerous things: What categories reveal about the mind. Chicago/London: The University of Chicago Press.

Lakoff, G. (1993). The contemporary theory of metaphor. In A. Ortoni (Ed.), Metaphor and thought (pp. 202-257). Cambridge: Cambridge University Press.

Lakoff, G. (2002). Moral politics. Chicago/London: The University of Chicago Press.

Lakoff, G., \& Johnson, M. (1980). Metaphors we live by. Chicago: The University of Chicago Press.

Lakoff, G., \& Johnson, M. (1999). Philosophy in the flesh: Embodied mind and its challenge to western thought. New York: Basic Books.

Lakoff, G., \& Turner, M. (1989). More than cool reason: A field guide to poetic metaphor. Chicago/London: The University of Chicago Press.

López Campillo, R. M. (2009). La Guerra de Sucesión Española: Opinión pública y propaganda política en Gran Bretaña durante el reinado de Ana Estuardo (The War of the Spanish Succession: Public opinion and political propaganda in Great Britain in the reign of Anne Stuart). ENSAYOS, Revista de la Facultad de Educación de Albacete, 24, 185-197.

López Campillo, R. M. (2010). Daniel Defoe y la Guerra de Sucesión Española (Daniel Defoe and the War of the Spanish Succession). Ann Arbor: ProQuest.

López Cirugeda, I., \& Sánchez Ruiz, R. (2013). Persuasive rhetoric in Barack Obama’s immigration speech: Pre- and post-electoral strategies. Camino Real, 5(8), 81-99.

López Cirugeda, I., \& Sánchez Ruiz, R. (2014). Conceptual metaphor in Michelle Obama's 2012 re-election speeches. ES. Revista de Filología Inglesa, 35, 129-150.

McKim, A. M. (2008). War of words. Daniel Defoe and the 1707 Act of Union. Journal of Irish and Scottish Studies, 1(2), 29-44.

McLeod, W. R., \& McLeod, V. B. (1979). Anglo-Scottish tract, 1701-1714: A descriptive checklist. Lawrence: University of Kansas Publications.

Monro, A. (d1715?). An apology for the clergy of Scotland chiefly oppos'd to the censures, calumnies, and accusations of a late Presbyterian vindicator, in a letter to a friend: wherein his vanity, partiality and sophistry are modestly reproved, and the legal establishment of episcopacy in that kingdom, from the beginning of the Reformation, is made evident from history and the records of Parliament: Together with a postscript, relating to a scandalous pamphlet intituled, an answer to the Scotch Presbyterian eloquence. London: Jos. Hindmarsh.

Müllenbrock, H. J. (1997). The culture of contention: A rhetorical analysis of the public controversy about the ending of the War of the Spanish Succession, 1710-1713. Munich: Fink.

Musolff, A. (2010). Political metaphor and bodies politic. In U. Okulska \& P. Cap (Eds.), Perspectives in politics and discourse (pp. 23-41). Amsterdam/Philadelphia: John Benjamins.

Oakleaf, D. (2008). A political biography of Jonathan Swift. London: Pickering \& Chatto.

Ridpath, G. (1707, August 30-1708, February 14). The Observator (Vol. 6). London: John Tutchin.

Ridpath, G. (1708, February 14-1709, January 29). The Observator (Vol. 7). London: John Tutchin.

Ridpath, G. (1694). The Scots episcopal innocence or the juggling of that party with the late King, His present Majesty, the Church of England, and the Church of Scotland demonstrated. London.

Sánchez Ruiz, R. (2014). Estrategias persuasivas y de manipulación ideológica en el discurso político: George Ridpath y la opinión pública inglesa durante la Guerra de Sucesión Española (1710-1713) (Persuasive and manipulative language in political discourse: George Ridpath and the British public opinion in the War of the Spanish Succession, 1710-1713) (Unpublished dissertation, University of Castilla-La Mancha).

Schonhorn, M. (1991). Defoe's politics: Parliament, power, kingship, and Robinson Crusoe. Cambridge: Cambridge University Press.

Speck, W. A. (1970). Tory and Whig: The struggle in the constituencies, 1701-1715. London: McMillan.

Swift, J. (1824). The works of Jonathan Swift. Edinburgh: A. Constable \& Co.. 
van Dijk, T. (1999). (Trans.). Lucrecia Berrone de Blanco. Ideología: Una aproximación multidisciplinaria (Ideology: A multidisciplinary approach). Barcelona/Buenos Aires: Gedisa.

van Dijk, T. (2001). Critical discourse analysis: An introduction. In D. Schiffrin, H. E. Hamilton, \& D. Tannen (Eds.), Handbook of discourse analysis (pp. 357-371). Oxford: Blackwell.

van Dijk, T. (2008). Discourse and power. New York: Palgrave Macmillan.

Wang, J. (2010). A critical discourse analysis of Barack Obama's speeches. Journal of Language Teaching and Research, 1(3), 254-261.

Wilson, J. (2001). Political discourse. In D. Schiffrin, H. E. Hamilton, \& D. Tannen (Eds.), Handbook of discourse analysis (pp. 398-416). Oxford: Blackwell.

Wodak, R., \& Chilton, P. (2005). A new agenda in (critical) discourse analysis: Theory, methodology and interdisciplinary. Amsterdam/Philadelphia: John Benjamins. 